\author{
D.B.Shayakhmetoval ${ }^{1}$, A.A.Tautenbayeva ${ }^{2}$ \\ ${ }^{1}$ Abay Kazakh National Pedagogical University \\ ${ }^{2}$ T.K. Zhurgenov Kazakh National Academy of Arts
}

\title{
PEDAGOGICAL MODELING IN PREPARING OF FUTURE PRIMARY SCHOOL TEACHERS FOR PROFESSIONAL SELF-DEVELOPMENT
}

\begin{abstract}
This article is devoted to the development of a model in preparing of future primary school teachers for professional self-education. Represented pedagogical model is a description and theoretical justification of its main blocks: target; content; technological; reflexive-evaluative; effective. The target block is formed taking into account the methodological basis, principles of functioning and social order, expressed in the form of requirements of educational and professional curriculum, employers and the labor market.Based on the fact that the content block performs teaching, developing, and research functions in the model, it is expressed in a comprehensive program for preparing students for professional self-education. The main purpose of the technological block is to determine the directions of social and pedagogical activity, organization and management of the educational process. Analysis, forecast and evaluation of performance results is carried out in accordance with the developed system for assessing readiness for professional selfeducation (reflexive-evaluation block).

Key words: self-education, professional self-education, professional competence, future primary school teachers, pedagogical activities and technologies, model, readiness, criteria and indicators of assessment.

$$
\begin{gathered}
\text { Шаяхметова Д.Б }{ }^{1}, \text { Таутенбаева А.А } \\
{ }^{1} \text { Абай атындавы Қазақ Ұлттық педагогикальқ Университеті } \\
{ }^{2}, \text { Т.Қ.ЖҮргенов атындавы Қазақ Ұлттық Өнер Академиясы }
\end{gathered}
$$

\section{БОЛАШАҚ БАСТАУЫШ МЕКТЕП МҰҒАЛІМДЕРІН ӨЗІН-ӨЗІ КӘСІБИ ДАМЫТУҒА ДАЯРЛАУДЫН ПЕДАГОГИКАЛЫҚ ҮЛГІСІ}

\begin{abstract}
Аңңдатпа
Бұл мақалада бастауыш сынып мұғалімдерін әртүрлі педагогикалық технологиялар негізінде өзін-өзі тәрбиелеуге дайындау мәселесі қарастырылған. Мақалада болашақ бастауыш сынып мұғалімдерін кәсіби өзін-өзі тәрбиелеуге дайындаудың үлгісі ұсынылған және оның негізгі блоктарын оқу үдерісін құру логикасына сәйкес теориялық негіздеу: мақсатты; мазмұны; технологиялық; рефлексивті-бағалау; тиімді. Модель интегративті болып табылады, ол нәтижеге қол жеткізу шарттарына сәйкес компоненттерді қосуға немесе алып тастауға мүмкіндік береді. Нысаналы блок білім беру және кәсіптік оқу бағдарламаларының, жұмыс берушілердің және еңбек нарығының талаптары түрінде көрсетілген әдістемелік негізді, жұмыс істеу қағидаттарын және әлеуметтік тәртіпті ескере отырып құрылады. Мазмұндық блогы студенттерді кәсіби өзін-өзі тәрбиелеуге дайындаудың кешенді бағдарламасында көрсетілген. Технологиялық блоктың негізгі мақсаты әлеуметтік-педагогикалық қызметтің бағыттарын, оқу үдерісін ұйымдастыру және басқару болып табылады. Нәтижелерді талдау, болжау және бағалау кәсіби өзін-өзі тәрбиелеуге дайындықты бағалаудың (рефлексивті-бағалау блогы) әзірленген жүйесіне сәйкес жүзеге асырылады.

Түйін сөздер: өзін-өзі дамыту, кәсіби құзіреттілік, болашақ бастауыш сынып мұғалімдері, педагогикалық іс-әрекеттер мен технологиялар, модель, дайындық, бағалау критерийлері.
\end{abstract}




\author{
Шаяхметова Д.Б ${ }^{l}$, Таутенбаева А. $A^{2}$ \\ ${ }^{1}$ КазНПУ им Абая \\ ${ }^{2}$ Казахская национальная академия искусств им. Т.К.Жургенова
}

\title{
ПЕДАГОГИЧЕСКОЕ МОДЕЛИРОВАНИЕ В ПОДГОТОВКЕ БУДУЩИХ УЧИТЕЛЕЙ НАЧАЛЬНЫХ КЛАССОВК ПРОФЕССИОНАЛЬНОМУ САМОРАЗВИТИЮ
}

\begin{abstract}
Аннотация
В данной статье рассматривается проблема подготовки учителей начальных классов к профессиональному самообразованию на основе различных педагогических технологий. Представленная в статье модель подготовки будущих учителей начальных классов к профессиональному самообразованию представляет собой описание и теоретическое обоснование его основных блоков в соответствии с логикой построения образовательного процесса: целевого; содержательного; технологического; рефлексивный-оценочного; результативного. Модель является интегративной, что позволяет добавлять или исключать компоненты в соответствии с условиями достижения результата. Целевой блок формируется с учетом методологической базы, принципов функционирования и социального порядка, выраженных в виде требований образовательной и профессиональной учебной программы, работодателей и рынка труда. Исходя из того, что контентный блок выполняет в модели функции обучения, развития и исследования, он выражается в комплексной программе подготовки студентов к профессиональному самообразованию. Основной целью технологического блока является определение направлений социально-педагогической деятельности, организации и управления образовательным процессом. Анализ, прогноз и оценка результатов деятельности проводится в соответствии с разработанной системой оценки готовности к профессиональному самообразованию (блок рефлексивно-оценочной деятельности).

Ключевые слова: профессиональное самообразование, профессиональная компетентность, будущие учителя начальных классов, педагогическая деятельность и технологии, модель, готовность, критерии и показатели оценки.
\end{abstract}

The paradigm of self-education existed and was constantly improved in pedagogy.It corresponded to the socio-economic demands of society regardless of the course of history.Of course, it has undergone major changes and has had its own peculiarities in various historical epochs [1].

The definition of "self-education" is part of the concept of "professional self-education" and carries the main semantic load. Currently, representatives of various sciences are engaged in the study of this problem: philosophy, sociology, psychology, pedagogy.

Traditionally, in the national literature "self-education" is considered in the area of psychological and educational knowledge.

The interpretations of the concept of "self-education" presented in the reference literature reflect a unified approach to its formulation [2; 3; 4].Thus, Educational Encyclopedia defines that self-education is "a purposeful cognitive activity, governed by the personality himself, acquiring systematic knowledge in any field of science, technology, culture, political life, etc." [5].

In the dictionary of pedagogy, the concept self-education is defined as "specially organized, independent, systematic, cognitive activity aimed at achieving certain personal and (or) socially significant educational goals: satisfaction of cognitive interests, general cultural and professional needs and professional development, which is usually based on the model of systematic forms of education, but is regulated by the subject itself" [6].In this definition, among the designated goals of self-education clearly visible the professional component of the concept, which allows us to argue that in this context it is synonymous with the concept of "professional self-education".

It should be noted that teachers in the countries participating in the Bologna Agreement have a common understanding and a list of professional competences throughout the period of professional activity of teachers. Their formation begins during the development of the professional program, and then the task of the teacher - to keep them up to date.

For example, in Germany, professional self-education is a sphere of competence - innovation, the essence of which is reduced to the need to understand one's profession as a task of continuous learning [7].In the logic of this, self-education is synonymous with professional self-education of the teacher [8].Based on 
the fact that the requirements for professional competencies are unchanged throughout the entire professional activity, during the period of study at a higher school in Germany, future teachers are involved in independent research work from the first year.

M. B. Belikaeva in her research notes that self-education of students in foreign higher education is associated with the formation of needs for continuous self-education after graduation from higher school; productive creative thinking; development of abilities for logical analysis and abilities for comprehensive processing of information consumed [9].

Among all professional competencies of a French teacher, J. Deauvieau identifies the desire for selfeducation and self-improvement as a special group, which emphasizes the need to work on oneself throughout the professional activity in various forms [10].

From a philosophical point of view, self-education is a process of knowledge that is subject to the basic laws of the theory of knowledge.The result of this process is new knowledge (knowledge of the essence, laws and relations of the objective world), which nourish creative activity (material and spiritual) [11].This is something without which it is impossible to update the cognitive component of a teacher's professional activity.

With regard to the sociology of education, this concept is defined as a specific type of human occupation outside of stationary forms of education without constant, systematic guidance of the teacher according to their own or someone's developed study plan [12].It should be added that the future specialist should be able not only to identify problem areas, but also to plan and organize their activities for the development of new knowledge, the formation of skills.Therefore, in the educational process, it is necessary to create the conditions for mastering the personality of these processes in full.

In the same vein, N.T. Ualieva considers the process of self-education. The authors believes that selfeducation is a process of acquiring general and specific (professional) knowledge on one's own initiative through self-organized and controlled classes [13].

Thus, the problem of self-education of the personality has a complex and multidimensional character.

Professional self-education in most sources is considered in the key of general trends of self-education, which is determined by its structure and content.At the same time, it has its own characteristics regarding the sphere of professional activity.Therefore, during the development of the educational curriculum of higher professional education, it is important to form the readiness of future primary school teachers for professional self-education, which acts as a professional competence that provides professional and personal development in accordance with the constantly changing demands of the labor market.

Based on the theoretical positions stated, we clarify the concept of "professional self-education", focusing on the reflexive activity of the teacher as the starting point for building the trajectory of his professional and personal development.

Focusing in this study on the content of the concept of "readiness for professional self-education", it is necessary, firstly, to justify it from the position of a competency-based approach; secondly, to determine its structure and designate components; thirdly, to clarify the content; fourthly, to consider the process of formation of readiness for professional self-education in the educational space of the University.

On the one hand, the readiness and ability of an individual to carry out professional activities is demonstrated by the formed list of competencies during the period of professional education.On the other hand, it shows the level of professional and personal development of the specialist.At the same time, rapid changes in the socio-economic sphere are constantly updating the requirements for the quality of his professional activity.

Modern scientists-educators define new requirements of the world of work for the personality and qualification:

- ability to engage in effective professional activities immediately after completing professional education;

- readiness for professional mobility;

- availability of socio-professional knowledge, skills that go beyond the educational curriculum [14].

Achieving a new quality of education that meets the challenges of the time is ensured by the construction of the educational process within the framework of the competency-based approach. What competencies and at what stage of professional education should be formed is a priority issue of the competency-based.

To this should be added one more characteristic difference of this approach - this is the integrated development of knowledge, skills, and experience.The results of education, represented by a certain set of 
competencies, reflect the balance of interests of society, the state, educational institutions, employers, and consumers of educational services.In line with this approach, the readiness and ability of future specialists to react independently and act in conditions of uncertainty to solve professional problems becomes the meaning of education.

The analysis of pedagogical literature and publications of researchers allows us to state that competence is a general ability and readiness of the students to mobilize in professional activities their own knowledge, skills, generalized ways of performing actions acquired in the course of training.

Our area of interest is competence as the final outcomes of the development of the educational curriculum for training specialists, i.e. professional competencies that ensure the performance of production tasks.

In the literature there is no single approach to determining the list of professional competencies.Its borders are not clearly defined.It is possible to identify professional competencies only in relation to the specific educational system in which the teacher works or will work, i.e. based on the types of professional activities.

A. K. Markova in her work in 1994 defines professional competence as the subject of a special comprehensive study and structurally presents it in four blocks:

1. Professional (objectively necessary) psychological and pedagogical knowledge.

2. Professional (objectively necessary) pedagogical skills.

3. Professional psychological positions, attitudes of the teacher required by the profession.

4. Personal characteristics that ensure the teacher's mastery of professional knowledge and skills [15].Later, the author identified special, social, personal and individual types of professional competence of the teacher.

All the above facts allow us to conclude that the readiness for professional self-education is the professional competence of the primary school teacher, which provides the solution of professional tasks, allows to plan and implement development based on the model of professional and personal development of the teacher.

Professional competence is the process of self-identification, awareness and overcoming the deficits of one's own professional activity on the basis of a reflective assessment of labor results, which we consider as a diverse professional activity of primary school teachers.In the logic of this, the components of readiness are:

- goal: readiness for professional self-education;

- motivational and value component: internal need for professional and personal development of the future primary school teacher;

- cognitive component (content): a system of knowledge about reflection as a means of assessing the level of professional development of the individual; methods of obtaining and mastering information as the main source of the process of cognition;

- technological component: a set of skills to eliminate skills deficits; experience in line with the identified knowledge and skills;

- reflexive and evaluative component, a system of knowledge and a set of skills for organizing and conducting self-assessment of own activities.

Successful entry and self-affirmation of the future primary school teacher in professional activities, his professional and personal development depends on how much in the years of professional education will be able to form a readiness for professional self-education.Only the immersion of a future specialist in the professional environment through the integration of theory and practice ensures the accumulation of a system of knowledge, the formation of skills and methods of activity, the assimilation of values and norms. The need for professional and personal development is one of the important points that determines the trajectory of his professional development.The solution to this problem is seen in the actualization of the educational process at the pedagogical University, which required the choice and application of an adequate research method in pedagogical practice - modeling.

Modeling as a method of scientific research is widely used in the theory and practice of education to solve a set of research problems. This is due to the fact that it helps to reproduce the integrity, indicate the structure, and represent the functioning of the subject under study. Analysis of the concept of "modeling" in relation to areas of scientific knowledge allows us to see its essential (methodological) characteristics. 
Under the "model", we understand the description and theoretical justification of significant components (blocks) of the University's educational space that ensure the achievement of the target results of this process.

The first stage of development of the model was to build the process of formation of professional competence "readiness for professional self-education" of primary school teachers.It is based on the generalized knowledge obtained as a result of theoretical study of the literature in the framework of this study.

At the second stage, the selection of components for the construction of the model was carried out, their relationship and interdependence were established.

The third stage was the process of directly creating a model that allowed a comprehensive review of the subject matter

In the process of modeling, the principles of functioning of the model are determined.These are: scientific, complexity, systematic, target orientation, optimality and efficiency, objectivity and specificity, and feedback.

Table 1. A pedagogical model in preparing future primary school teachers for professional self-education

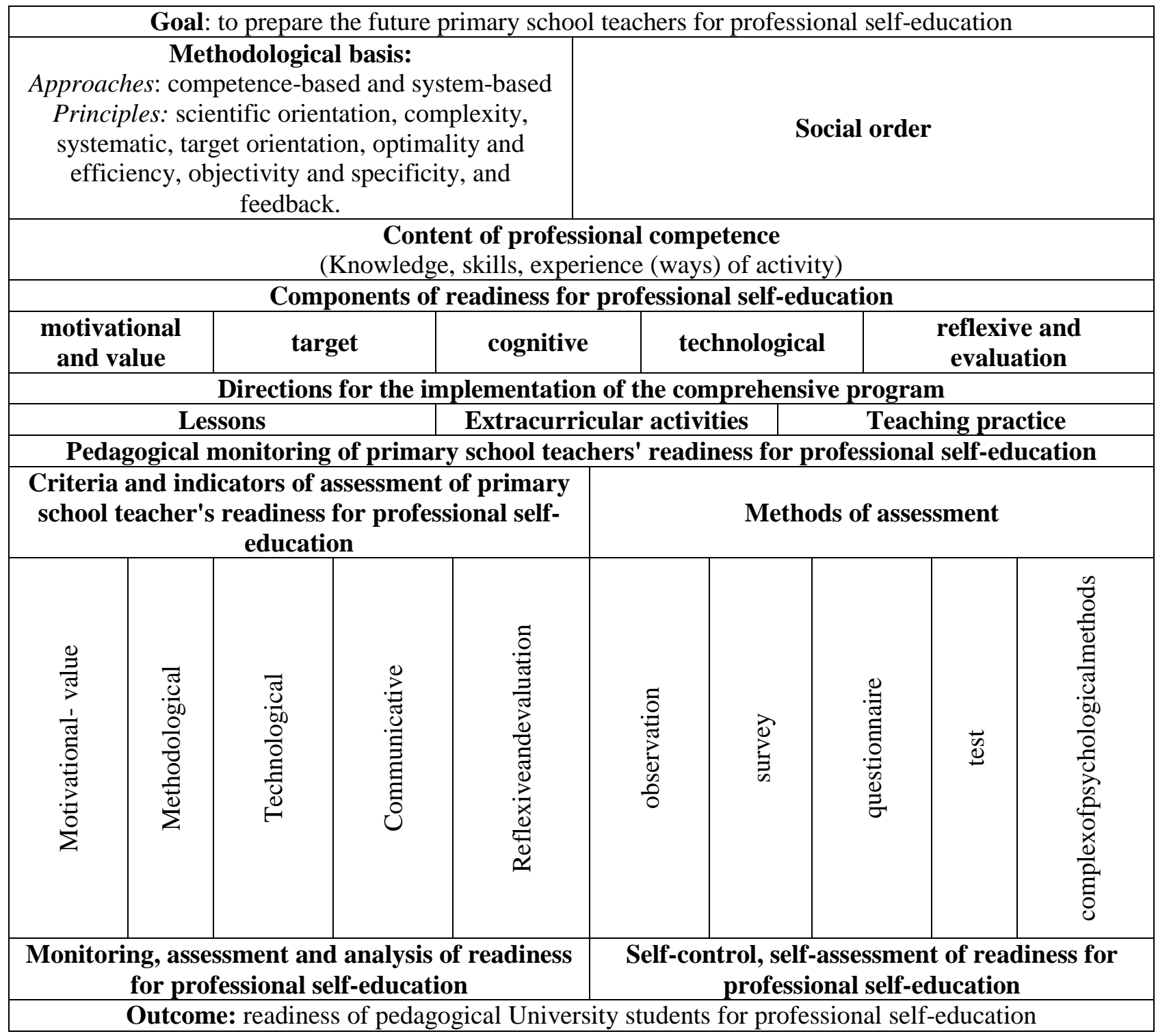

The implementation of the model involves the definition and creation of organizational and pedagogical conditions that ensure the formation of students ' readiness for professional self-education. The model allows you to adjust and design pedagogical tools for forming students' readiness for professional self- 
education;gives an idea of the pedagogical diagnostics of students' readiness for professional self-education; updates the educational space of the University through social partnership.

The results of the analysis of the content of academic disciplines, professional modules, and teaching practice tasks predetermined the selection of educational technologies as a technological component for the implementation of the model.

Among the available range of pedagogical technologies is a group of communication and project techniques, which most effectively provide the transmission of theoretical knowledge to the area of social and educational practice and contribute to acquiring knowledge, skills, accumulating and expanding the experience of the future primary school teacher and, as a result, contribute to the formation of a readiness for self-education.

The educational process uses techniques of round tables, panel discussions, "Zebra" technique, "Fifth corner", "Aquarium", "Binary discussions", debates, and other types of the dialogue model of teaching.

It is important that the use of the dialogue modelinvolves expanding the range of knowledge about the subject, the phenomenon of discussion.Therefore, working with information takes a leading place in this process. The dialogue model of teaching is widely used for students of 1-2 years of study, since during this period the emphasis is placed on the broad development of professional knowledge.

A teaching workshop is a technique that requires a teacher to move to a partnership position.A number of authors consider the workshop as a technology aimed at immersing participants of the educational process to search for new knowledge, as well as self-knowledge.The workshop creates conditions for future primary school teachers to gain experience.Each workshop participant has the right to choose from the partner's preference, project ideas, and the way to present their results.The workshop refers directly to the practice, considering the practical activities of the teacher; therefore, teachers refer to the workshop if there is a certain theoretical basis for the purpose of enriching practical experience.The combination of this technique with interactive and ICT technologies contributes to the development of self-awareness and selfactualization, professional mobility.

The pedagogical studio is a laboratory of pedagogical creativity. At the base of the studio, there are three key methods:

- illustrative, providing pedagogical professional presentation of the phenomenon that is studied in the studio;

- an ordinary analogy that allows to build a logical bridge from everyday ideas to scientific generalizations, concepts;

- exercises that form the necessary skills for the implementation of the pedagogical plan.

Based on these positions, lessons in the format of a pedagogical studio are held on the 3rd-4th years of study.

Project technique helps to expand the social and pedagogical experience of the future primary school teacher.The development and implementation of projects in the educational process of the university makes it possible to form social and personal qualities of the personality in relation to the external environment.Project technique allows to transfer the student from a passive participant in the educational process to an active subject of socio-economic relations.This is achieved by maximizing the intellectual potential of the future primary school teacher in the interests of society's development.

The use of project techniques in the educational process qualitatively changes the functions of the teacher and student. The teacher and the student become equal subjects of the educational process, the teacher acts as a consultant-coordinator.It is important that in project, students constantly turn to the analysis of reality in order to identify urgent and promising problems, find ways to solve and transform them.It is noteworthy that, on the one hand, the finished project is a description of any problem, concrete "steps" for its implementation, that is, a model of proposed changes in a particular area.On the other hand, it is a means of managing cognitive activity in the process of professional education.

Features of the project technique of future primary school teachers is that:

- it draws attention to current social and pedagogical problems and ensures the inclusion of the individual in a variety of activities to solve them;

- participants have the opportunity to "example" different social roles depending on the direction, purpose and objectives of the problem being implemented, which ultimately contributes to the development of their own life position, the formation of a worldview, adequate self-esteem, form social experience;

- subjects of social partnership can act as full participants of the project; 
- social partnership can act as a mechanism for the implementation of project activities, which allows to ensure the scale, integrity, efficiency of interaction of various social institutions that affect the process of personality's socialization.

- The positive attitude of students to project techniques has become a criterion for assessing the result of this type of professional activity.The assessment indicators are formulated as follows:

- social activity of students (number of people taking part in project activities);

- number of independently developed and implemented projects;

- formation of social and moral attitudes, values, and norms of behavior (evaluated on the basis of standardized psychological and pedagogical methods).

Information technologies (IT) used by teachers throughout the entire period of study at the University (practical classes, extracurricular independent work), stimulated the process of self-education of students.It should be noted that the scope, content, design and presentation of the results of the activity gradually became more complicated from 1 year to 4 years of studying.The role of the teacher and the student in this process changed.

When using information technologies in the educational process of the University in the framework of experimental activities, we assumed that IT:

- provide work with various sources of information, which contribute to the development of knowledge and the formation of skills to work with information - a cognitive component of readiness for professional self-education;

- they form time management skills by mastering the tools for working with information - a technological component of readiness for professional self-education;

- contribute to creative self-realization through the creation of individual information products -a methodological component of readiness for professional self-education;

- form skills for evaluating information resources on the Internet - a technological and reflexiveevaluating component of readiness for professional self-education.

It is also important that future primary school teachers used educational resources to assess the assimilation of educational content in the classroom, and then passed the experience into professional activity during the period of pedagogical practice.

The experience of practical activities in the use of pedagogical technologies in the educational process of the University in the presented logic proves that:

- there is a development of the knowledge system, mastering skills, enriching and increasing the experience of activity;

- there is a formation and development of social activity, professional mobility, awareness of the importance of own activities;

- logical transfer of theoretical knowledge to the plane of practice;

- there is a logical transfer of theoretical knowledge to the plane of practice.

- In addition, the skills of practical research are formed, the skills of professional decision- making, creating mechanisms for independent searching for the necessary information, developing personal value orientations, cognitive activity, creativity are increasing.

- Finally, in the process of realizing the model, the University has accumulated experience in implementing club, volunteer activities and other forms of upbringing work in order to expand the social and pedagogical practice of future primary school teachers.

- Club activities at the University are implemented in three directions:

- traditional is the search and dissemination of information within the framework of historical, local history, patriotic, ethno-national, spiritual and moral direction. Goal: preservation of traditions and the perpetuation of memorable dates and events, chronicles, etc. An example of this is meetings with writers, journalists, veterans, employees of state and law enforcement agencies, with interesting people.

- socially-oriented - these are actions, to solve social problems, multimedia projects, agitation and propaganda activities, participation in election campaigns with the orientation of young people to fulfill their civic duty, etc.

- analytical-organizational - is the examination of projects, results of social practices; analysis and forecast of the development of situations in the social environment using sociological surveys, questionnaires and other forms of research. 
The volunteer movement is a movement related to solving problems in educational organizations. The peculiarity of the volunteer movement is the participation of students in conducting trainings with different categories of the population.

Thus, the materials obtained in this part of the article allowed us to determine the complex of organizational and pedagogical conditions for the formation of readiness for professional self-education of primary school teachers. These are:

- development of a model for preparing future primary school teachers for professional self-education;

- the inclusion of future primary school teachers in a variety of social and pedagogical activities: educational, research, project, and extracurricular activities: club, volunteer with the aim of forming readiness for professional self-education;

- defining a system of criteria and indicators for assessing the readiness of the future primary school teachers for professional self-education.

As part of the experimental work, a study was conducted to assess the readiness of future primary school teachers for professional self-education.The study was carried out during the formative and generalizing stages of the work.Comparison of the obtained results allows us to draw a conclusion about the effectiveness of the University's activities in this direction.

In the process of evaluating the results of experimental work such methods as: monitoring students in natural conditions (lessons, extracurricular activities, pedagogical practice), interview, questionnaire were used.

In the course of experimental work on testing the pedagogical model, positive results were obtained that demonstrate the effectiveness of activities and techniques in the formation of readiness for professional selfeducation of future primary school teachers.

\section{References:}

1. Medvedev, I. F. Koncepciasamoobrazovaniya:osnovniyeponyatiyaistruktura // Obrazovaniyeinauka. Moskva, 2012. - No. 2 (91), - S. 32-42.

2. Abdigaparova U.M. et.al. Formation of the professional self-improvement competence formation of the University students. Procedia Social and Behavioral sciences (Scopus) www.elsvier .comlocate / procedia CY-ICER 2013.

3. Sarybekov M.N., Sydyknazarov M.K. Slovarnauki. Obschenauchnie termini I kategirii. Izdatelstvo: Almaty: TRIUMF-T. - 2008. - $504 \mathrm{~s}$.

4. Sydykbayeva A.D., Khan N.I. Issledovatelskayakompetenciabuduschegouchitelyanachalnikhklassov // nauchniyzhurnal "Vestnik" ENU im. L.N. Gumileva. - №3 (106). - 2015. C.335-340.

5. Pedagogicheskiyslovar. Uchebnoeposobiedlyastudentovvisshikhuchebnikhzavedeniy V.I.Zagvyazinskiy, A.F. Zakirova. Moskva? Izdatelskiycentr "Akademiya", 2008, - 325 p.

6. Kodzhaspirov, G.M., Kodzhaspirov, A.Y. Dictionary of pedagogy. / G.M. Kojaspirova, A.Yu. Kojaspirov - Moscow: MarT, 2005. - 448 p.

7. Standards fuer die Lehrerbildung: Bildungswissenschaften: Beschluss der Kultusministerkonferenzvom 16.12.2004. [Electronic resource] - URL: http://lakk.sts-gymmarburg.bildung.hessen.de/modul/KMK_Standards_Lehrerbildung.pdf.

8. Ebner, K. Die Erfassung von Kompetenzen und Potenzialen / Katharina Ebner. - Literaturangaben, Abb. In: ZukunftsfeldBildungs- und Berufsberatung: neueEntwicklungenausWissenschaft und Praxis / Katharine Ebner [Hrsg.]. - Bielefeld. - S. 131-140.

9. Belikayeva, M.B. Forms of organizing self-education of students abroad to form professional mobility. Moscow: 2008.

10. Deauvieau J. Constitution du savoir professionnel à l'entréedans le métier : Le cas des enseignants du secondairel/ Comité de Recherche 52, Sociologie des Groups professionnels, 4e conférenceintérimaire. Septembre 2004. - Pp. 22-24.

11. IlyinV.V.Filosoaskayaantropologiya. 2-e izd.,Moskva, knizhniydom "Universitet", 2008, - 231 s.

12. Voronin A.S. Slovarterminovpoobschey I socialnotpedagogike. Ekaterenburg, 2008, - $135 \mathrm{~s}$.

13. Ualieva

N.T.

Psykhologopedagogicheskieusloviyaorganizaciisamostoyatelnoirabotystudentovnaosnovekompetentnostnogopodkhoda. Disser.PhD, Almaty, 2016.

14. Professionalnayapedagogika. Chast. 1: Uchebnoeposobiedlyavuzov / Pod obscheyredakciey V.I. Blinova. - Moskva: IzdatelskiydomYurayt, 2017.- 372 s.

15. Markova, A.K. Psychology of professionalism / A.K. Markova. - Moscow: International humanitarian Fund "Knowledge", 1996. - 312 p. 